University of Nebraska - Lincoln

DigitalCommons@University of Nebraska - Lincoln

USDA Forest Service / UNL Faculty Publications U.S. Department of Agriculture: Forest Service --

National Agroforestry Center

April 2004

\title{
Computer-based tools for decision support in agroforestry: Current state and future needs
}

\author{
E. A. Ellis \\ University of Florida, PO Box 110410, Gainesville, FL \\ G. Bentrup \\ USDA National Agroforestry Center, USFS Rocky Mountain Research Station \\ M. M. Schoeneberger \\ 2USDA National Agroforestry Center, USFS Rocky Mountain Research Station
}

Follow this and additional works at: https://digitalcommons.unl.edu/usdafsfacpub

Part of the Forest Sciences Commons

Ellis, E. A.; Bentrup, G.; and Schoeneberger, M. M., "Computer-based tools for decision support in agroforestry: Current state and future needs" (2004). USDA Forest Service / UNL Faculty Publications. 4. https://digitalcommons.unl.edu/usdafsfacpub/4

This Article is brought to you for free and open access by the U.S. Department of Agriculture: Forest Service -National Agroforestry Center at DigitalCommons@University of Nebraska - Lincoln. It has been accepted for inclusion in USDA Forest Service / UNL Faculty Publications by an authorized administrator of DigitalCommons@University of Nebraska - Lincoln. 


\title{
Computer-based tools for decision support in agroforestry: Current state and future needs
}

\author{
E.A. Ellis ${ }^{1, *}$, G. Bentrup ${ }^{2}$ and M.M. Schoeneberger ${ }^{2}$ \\ ${ }^{1}$ School of Forest Resources and Conservation, University of Florida, PO Box 110410, Gainesville, FL 32611- \\ 0410, USA; ${ }^{2}$ USDA National Agroforestry Center, USFS Rocky Mountain Research Station, UNL-East Campus, \\ Lincoln, Nebraska 68583-0822, USA; *Author for correspondence: e-mail: eaellis@ufl.edu
}

Key words: Databases, Decision Support Systems, Geographical Information Systems, Models

\begin{abstract}
Successful design of agroforestry practices hinges on the ability to pull together very diverse and sometimes large sets of information (i.e., biophysical, economic and social factors), and then implementing the synthesis of this information across several spatial scales from site to landscape. Agroforestry, by its very nature, creates complex systems with impacts ranging from the site or practice level up to the landscape and beyond. Computer-based Decision Support Tools (DST) help to integrate information to facilitate the decision-making process that directs development, acceptance, adoption, and management aspects in agroforestry. Computer-based DSTs include databases, geographical information systems, models, knowledge-base or expert systems, and 'hybrid' decision support systems. These different DSTs and their applications in agroforestry research and development are described in this paper. Although agroforestry lacks the large research foundation of its agriculture and forestry counterparts, the development and use of computer-based tools in agroforestry have been substantial and are projected to increase as the recognition of the productive and protective (service) roles of these tree-based practices expands. The utility of these and future tools for decision-support in agroforestry must take into account the limits of our current scientific information, the diversity of aspects (i.e. economic, social, and biophysical) that must be incorporated into the planning and design process, and, most importantly, who the end-user of the tools will be. Incorporating these tools into the design and planning process will enhance the capability of agroforestry to simultaneously achieve environmental protection and agricultural production goals.
\end{abstract}

\section{Introduction}

'Few things disappoint a landowner more than spending money, time, and effort on a project that fails ... especially one like agroforestry, where it can be years before problems become apparent'

(Dosskey and Wells 2000).

Agroforestry, the deliberate integration of trees into crop and livestock operations, has the potential to achieve many of the environmental, economic, and social objectives being demanded from working landscapes by landowners and society. By adding structural and functional diversity to the landscape, these tree-based plantings can perform ecological functions that have significance far greater than the relatively small amount of land they occupy (Guo 2000; Nair 2001; Ruark et al. 2003). Realizing this potential is, however, a complex task of determining what opportunities, limitations, and trade-offs exist in each situation, and of designing an agroforestry practice that achieves the best balance among them. There are numerous impacts created by agroforestry plantings, ranging from intended to nonintended and, therefore, ranging from detrimental to advantageous, occurring both on- and off-site, and varying over time. Consequently, if agroforestry is to be a viable strategy in promoting agroecosystem sustainability, the decisionmaking process must incorporate many considerations, not only at the practice scale but also at the larger scales of farm, landscape, and watershed (Schoene- 
berger et al. 1994). Simply put, agroforestry creates a complex system of interactions that must be managed for multiple objectives, multiple alternatives and multiple social interests and preferences, while being applied over a wide range of landscapes and landscape features.

The decision-making process involved in agroforestry research, development and application is composed of several components: the person or group making the decision, the problem, the approach or method to solve the problem, and the decision. Decision support tools (DST) are a wide variety of technologies that can be used to help integrate diverse and large sets of information. DSTs do not replace the decision-making by the landowner or natural resource manager, but they do facilitate the decision-making process by making the planning process more informed and more objective (Grabaum and Meyer 1998). Although agroforestry, like most natural-resource management sciences, is characterized by high complexity of which we have limited understanding and data (Sanchez 1995; Nair 1998), the science and application of agroforestry can be greatly enhanced through the use of these tools.

\section{Computer-based decision support tools in natural resource management}

Computers now play an integral role for information management and decision-making in all disciplines related to natural resource management. Constant accretion of data and information on agriculture, forestry, agroforestry, and natural resource management has created the need to synthesize, organize and manipulate this growing knowledge base and facilitate its accessibility and use for education, research, and decision-making (Davis 1988; Schmoldt and Rauscher 1996). The complexity of natural resource management, considering the diversity of resources, interests, objectives, constraints, and stakeholders involved, adds to the difficulty of making sound management decisions (Schmoldt and Rauscher 1996). Computerbased DSTs provide an effective means to compile and sort out the medley of variables, information and knowledge (quantitative, qualitative, spatial, and heuristic) that managers must consider when making informed management decisions. In other words, DSTs synthesize the wide array of information and offer a holistic approach for evaluating land and resource management problems and finding appropriate solutions (Schmoldt and Rauscher 1996). There are five major categories of computer-based technologies used for decision support: databases, geographical information systems (GIS), computer-based models, knowledge-based or expert systems (KBS), and hybrid systems (Table 1).

In the past decade the use of computer-based technologies in agriculture, forestry, and natural resource management has been impressive. In the field of agriculture, the use of computers can be considered part of the agricultural revolution of the $20^{\text {th }}$ century, advancing scientific research, facilitating farm management, and improving production (Paarlberg and Paarlberg 2000). The development of crop models, expert systems for agricultural management, and precision farming that incorporates GIS has advanced considerably and are being used in many farming operations (NRC 1997; Zazueta and Xin 1998; Ahuja et al. 2002). Forestry, compared to production agriculture, is often faced with more complex and multiple objective management scenarios. The adoption and use of computers for decision support in forestry have had to evolve from simpler mathematic models used for harvesting scheduling to more complex computer DSTs used to help make management decisions where timber production must be balanced with wildlife conservation, water quality, recreation, and other objectives, often involving policy and social issues (Rauscher 1999). Table 2 lists some of the more recognized DSTs used in agricultural and forest management and describes their degree of complexities and integration of the major computer-based technologies.

\section{Databases}

Databases are computer-based tools used to access and query large quantities of data and information. They are often key components within other DSTs. The database DST consists of a database (a logically coherent collection of data) and a database management component (the software system), which allows a user to define, create, and maintain a database (Mata-Toledo and Cushman 2000). Computer databases are often implemented as a Relational Database Management System (RDBMS), designed around the mathematical concepts of relational algebra linking together two-dimensional data tables (Sanders 2000; Sunderic and Woodhead 2001). Query statements can be developed, allowing users to search and analyze data as well as extract specific information from huge datasets. This ability to extract pieces of informa- 
Table 1. Major categories of computer-based decision support technologies.

\begin{tabular}{|c|c|}
\hline Category & Description \\
\hline Databases & $\begin{array}{l}\text { Organizes and facilitates the management and querying of large quantities of data and } \\
\text { information }\end{array}$ \\
\hline Geographical Information Systems (GIS) & $\begin{array}{l}\text { Brings in a geographic or spatial component to a database; manages, manipulates and } \\
\text { analyzes spatial data }\end{array}$ \\
\hline Computer-Based Models & $\begin{array}{l}\text { Mathematical computer models that represent real world processes and predict outcomes } \\
\text { based on input scenarios }\end{array}$ \\
\hline Knowledge-Based or Expert Systems & $\begin{array}{l}\text { Adopts 'Artificial Intelligence' in the form of organizing, manipulating and obtaining } \\
\text { solutions using knowledge in the form qualitative statements, expert rules (i.e. rules } \\
\text { of thumb) and a computer language representation system for storing and manipulating } \\
\text { knowledge. }\end{array}$ \\
\hline Hybrid Systems & $\begin{array}{l}\text { Integrates two or more of the above computer-based technologies (e.g. (GIS, KBS and } \\
\text { Models) for more versatile, efficient and comprehensive DSTs. }\end{array}$ \\
\hline
\end{tabular}

Table 2. Computer-based decision support tools used in agricultural and forestry management.

\begin{tabular}{|c|c|c|}
\hline Decision support tool & Description & Reference \\
\hline GOSSYM-COMAX & $\begin{array}{l}\text { Used for management of water, nitrogen, herbicide and growth regulator in } \\
\text { cotton }\end{array}$ & $\begin{array}{l}\text { Reddy et al. 2002; } \\
\text { Gertsis and Whisler 1998; }\end{array}$ \\
\hline GLYCM & Soybean production model & $\begin{array}{l}\text { Timlin et al. 2002; } \\
\text { Acock et al. } 1997 \\
\text { Manning } 1996\end{array}$ \\
\hline CERES & Production model for crops in the tropics and subtropics & $\begin{array}{l}\text { Ritchie and Otter 1985; } \\
\text { Ahuja et al. } 2002\end{array}$ \\
\hline CROPGRO & Production model for crops in the tropics and subtropics & $\begin{array}{l}\text { Boote et al. 1998a; } \\
\text { Boote et al. 1998b; } \\
\text { Ahuja et al. } 2002\end{array}$ \\
\hline DSSAT & $\begin{array}{l}\text { Package of crop-soil models to facilitate the evaluation and application of dif- } \\
\text { ferent cropping systems and the input and organization of relevant scientific } \\
\text { data }\end{array}$ & $\begin{array}{l}\text { Jones et al. } 1998 \text {; } \\
\text { Jones et al. } 2003\end{array}$ \\
\hline FORPLAN/SPECTRUM & $\begin{array}{l}\text { Optimization models for forest management to evaluate financial efficiency, } \\
\text { land allocation and resource scheduling }\end{array}$ & $\begin{array}{l}\text { Field } 1984 \\
\text { Kent et al. } 1991 \\
\text { Rauscher } 1999\end{array}$ \\
\hline STEWPLAN & $\begin{array}{l}\text { Knowledge-based computer tool to assist landowners develop stewardship } \\
\text { plans based on forest stand descriptions. }\end{array}$ & Knopp and Twery 2003 \\
\hline$N E D$ & $\begin{array}{l}\text { Hybrid decision support tool integrating forest models, GIS, graphic visualiz- } \\
\text { ation and a knowledge base for multi-use forest management. }\end{array}$ & $\begin{array}{l}\text { Twery et al. 2000; } \\
\text { Twery et al., } 2003\end{array}$ \\
\hline$E M D S$ & $\begin{array}{l}\text { Landscape scale tool that integrates GIS, knowledge-based reasoning and } \\
\text { decision modeling technologies for ecosystem management decision support. }\end{array}$ & $\begin{array}{l}\text { Reynolds et al. 2002; } \\
\text { Rauscher } 1999\end{array}$ \\
\hline EPIC & $\begin{array}{l}\text { Erosion-Productivity Impact Calculator determines relationships between soil } \\
\text { erosion and crop productivity }\end{array}$ & $\begin{array}{l}\text { Jones et al. 1991; } \\
\text { Easterling et al. } 1997\end{array}$ \\
\hline CO2FIX & $\begin{array}{l}\text { Estimates and evaluates dynamics of carbon in forest management and } \\
\text { afforestation projects }\end{array}$ & Masera et al. 2003 \\
\hline
\end{tabular}


tion based on user-specified criteria makes a RDBMS an excellent computer-based technology for decision support. A multitude of natural-resource-related databases (i.e., ecosystems, flora, fauna, soils, hydrology, etc.) are now widely available and used in management decisions.

\section{Geographical information systems}

A GIS can be defined as a data management system designed to input, store, retrieve, manipulate, analyze, and display spatial data for the purposes of research and decision-making (De Mers 1997). In a GIS, a database is associated with map features, and data values are geographically referenced, so resource managers can spatially represent information such as soil types or plant communities. Since land use and a diversity of related disciplines (i.e., agriculture, forestry, rural planning, and conservation) all deal with spatial characteristics of landscapes (Lacher 1998), GIS has gained considerable use in land use planning and natural-resource management, providing a spatial framework to aid in the decision-making process (Zeiler 1999).

Additional technologies are often associated with GIS, such as Global Positioning Systems (GPS) and remote sensing. GPS is a means for inputting spatial data with real world coordinates into a GIS and has become an important tool for researchers locating and recording information in the field. Remote sensing involves using spatial data from photographic and satellite images, and software tools to analyze and interpret these data.

\section{Computer-based models}

For the most part, computer-based models refer to the translation of data and information into a mathematical form using algorithms to represent a real world 'process' or 'system' and to forecast outcomes of different scenarios. In the realm of environmental and natural-resource related fields, these models try to mathematically represent ecological processes (Skidmore 2002). Environmental models mathematically define ecological interactions and processes between biotic and abiotic components based on current or past conditions or states of these components. The goal of these models is to quantitatively predict future states of these components, serving a valuable role in defining the key processes in agroforestry practices (Peng et al. 2002; Skidmore 2002).

\section{Knowledge-based systems}

Knowledge-Based Systems (KBS) or expert systems are part of the broad field of Artificial Intelligence (AI) involving the creation of computer programs that attempt to mimic human intelligence or reasoning, 'learn' new information and tasks, and draw useful conclusions about the world around us (Patterson 1990). In a KBS, knowledge is defined as a 'body of facts and principles accumulated by humankind or the act, fact or state of knowing' (Patterson 1990). KBS are used to acquire, organize and manipulate knowledge, often using heuristic rules, analogous to 'rules of thumb' or 'good judgments,' to help make sound deductions (Nikolopoulos 1997). Often, experts in the subject are used to define these rules; however, knowledge for a KBS can be acquired from the literature, databases or other sources. A 'knowledge engineer' extracts knowledge, information and data from experts and other sources and translates it into programming languages so a computer can utilize and reason with it (Nikolopoulos 1997; Patterson 1990; Schmoldt and Rauscher 1996). With an appropriate user interface, the user can input problem scenarios and make enquiries to find solutions (Nikolopoulos 1997).

\section{Hybrid systems}

Many DSTs today integrate a variety of computerdecision support technologies such as RDBMS, GIS, Models and KBS (Davis 1988; Liebowitz 1990). Increasingly, land-use planning and natural-resource management DSTs are merging GIS and KBS to develop very effective and efficient spatial planning tools (Loh and Rykiel 1992). Nowadays, application development programs, modeling tools and GIS software are designed to be compatible with other systems and allow a relatively easy integration of the different computer-based technologies.

\section{Applications of computer-based DSTs for agroforestry}

Considerable advances have been made in research, planning and development for a variety of agroforestry systems in a wide range of agroecological regions, from tropical to temperate. Prior to 1991, computer use in agroforestry research began with the development of databases as aids in guiding plant selection (Nair 1998). As the use of agroforestry has broadened 
to address such issues as climate change and crop growth, carbon sequestration, biodiversity and even green infrastructure, so has the need to simulate agroforestry's longer-term effects across larger scales, further necessitating use of computer-based DSTs. These early DSTs used in agroforestry were generally those already in place in the fields of agriculture and forestry. For instance, the effect of shelterbelts on maize productivity under hypothesized climate change scenarios was examined using the ErosionProductivity Impact Calculator (EPIC) crop model, an agricultural model originally developed to determine the relationship between soil erosion and crop productivity (Jones et al. 1991; Easterling et al. 1997). Even today, many of these models developed for agriculture or forestry are still a first choice for use in agroforestry exercises. CO2FIX, a user-friendly model for dynamically estimating the carbon sequestration potential of forest management and afforestation projects, is readily adaptable for agroforestry (Masera et al. 2003).

Today we have several DSTs developed exclusively for agroforestry applications for the purposes of selecting suitable species, identifying suitable lands, modeling different systems and predicting outcomes of different scenarios. Several different types of computer-based DSTs that have been applied or are strongly applicable to agroforestry research, planning and development are listed in Table 3 and are discussed in further detail below. Additionally the intended uses, targeted end-users and current status of these major agroforestry DSTs are summarized in Table 4.

\section{Agroforestry databases}

An initial effort to use computers to manage agroforestry data began in the late 1980s with the Agroforestry Systems Inventory Database (AFSI) developed by the International Centre for Research in Agroforestry (ICRAF), now the World Agroforestry Centre. AFSI involved a global collection of data or information on agroforestry systems using a questionnaire as the survey instrument. Data and information collected and entered into the database included general description, geographical location, biophysical characteristics, socioeconomic aspects, system evaluation, components of the system and their uses, and identification of research gaps. With AFSI, the user is able to query the database, extracting information such as geographical locations of different agroforestry systems and the species found within these systems in different locations (Nair 1987; Oduol et al. 1988). AFSI was apparently developed as a research and information tool for researchers, particularly in ICRAF. No documentation could be found about current versions or availability of AFSI. Unfortunately, many early DSTs like AFSI often fail to be maintained and upgraded and therefore fade with time.

Another early agroforestry database was the MultiPurpose Tree and Shrub Database (MPTS), also developed by ICRAF in 1991 (von Carlowitz et al. 1991). The MPTS database, developed for researchers and extension agents, helped to select the right tree or shrub species for agroforestry practices, primarily for the tropics and subtropics. MPTS Database Version 1.0 contained information for 1093 species including site-specific requirements (e.g., soils), morphological and phenological descriptions, management characteristics and environmental responses (Schroder and Jaenicke 1994). A simple climate model was included to predict climatic conditions based on the input of geographical coordinates, and tree and shrub species were selected via a database search or query that matched the descriptors that the user selected. The descriptors included 19 different criteria covering aspects of location, climate and soil conditions, products, environmental services, management and cultivation. The user was also able to use boolean operators (i.e., and, or, and not) to fine-tune the search to their specific needs. References are also included to provide further information on selected agroforestry species (Schroder and Jaenicke 1994).

The current and revised version of MPTS is now the AgroforesTree Database (AFT). Unlike its predecessor this database is more widely accessible and available on the Internet and as a CD-ROM. It is a database management system intended for use by researchers and fieldworkers to select agroforestry trees that are being deliberately grown and managed for more than one output and expected to make significant economic and/or ecological impacts (Salim et al. 1998; World Agroforestry Centre 2003a). More than 300 species are incorporated into AFT with information on ecology and distribution, propagation and management, functional uses and pest and diseases (Salim et al. 1998). With AFT, users are able to search and select trees according to geographical location, biophysical limits and other management criteria selected. In addition, there are references, research contacts, a seed supplier's directory, images of trees, and a glossary of terms to help agroforesters obtain vital information and make wise decisions concern- 
Table 3. Computer-based decision support tools used in agroforestry.

\begin{tabular}{|c|c|c|c|}
\hline Decision support tool & Type & Description & Reference \\
\hline $\begin{array}{l}\text { AFSI } \\
\text { (Agroforestry Systems Inventory } \\
\text { Database) }\end{array}$ & Database & $\begin{array}{l}\text { Agroforestry system inventory database describ- } \\
\text { ing geographic location and biophysical, socioeco- } \\
\text { nomic and species characteristics }\end{array}$ & $\begin{array}{l}\text { Nair 1987; Oduol et al. } \\
1988\end{array}$ \\
\hline $\begin{array}{l}\text { MPTS } \\
\text { (Multipurpose Tree and Shrub } \\
\text { Database) }\end{array}$ & Database & $\begin{array}{l}\text { Multi-purpose tree and shrub database used for tree } \\
\text { selection and species information }\end{array}$ & $\begin{array}{l}\text { Schroder and Jaenicke } \\
1994\end{array}$ \\
\hline AgroforesTree Database & Database & $\begin{array}{l}\text { Internet and CD-Rom application for reference and } \\
\text { selection guide of agroforestry trees. }\end{array}$ & $\begin{array}{l}\text { Salim et al. 1998; } \\
\text { World Agroforestry } \\
\text { Centre 2003a }\end{array}$ \\
\hline $\begin{array}{l}\text { Subtropical Tree and Shrub } \\
\text { Database }\end{array}$ & Database & $\begin{array}{l}\text { On-line database on potential agroforestry tree and } \\
\text { shrub species for the American subtropics. }\end{array}$ & Ellis et al. 2003 \\
\hline Forestry Compendium & Database & $\begin{array}{l}\text { Compilation of knowledge on forestry, agroforestry } \\
\text { and plantations and information on trees for man- } \\
\text { agement decision-making and species selection }\end{array}$ & $\begin{array}{l}\text { CABI 1998; } \\
\text { Kleine et al. } 2003\end{array}$ \\
\hline $\begin{array}{l}\text { Agroforestry System Suitability in } \\
\text { Africa }\end{array}$ & GIS & $\begin{array}{l}\text { Spatial analysis using climate, soil land use and } \\
\text { other spatial data alongside plant species data to } \\
\text { determine species and agroforestry suitability }\end{array}$ & $\begin{array}{l}\text { Booth et al. 1989; } \\
\text { Booth et al. 1990; } \\
\text { Unruh and Lefebvre } \\
1995\end{array}$ \\
\hline $\begin{array}{l}\text { Agroforestry System Suitability in } \\
\text { Ecuador }\end{array}$ & GIS & $\begin{array}{l}\text { Spatial analysis to determine suitable areas of } A n \text { - } \\
\text { nona cherimola agroforestry systems in Southern } \\
\text { Ecuador. }\end{array}$ & Bydekerke et al. 1998 \\
\hline $\begin{array}{l}\text { Agroforestry System Assessment } \\
\text { in Nebraska }\end{array}$ & GIS & $\begin{array}{l}\text { Spatial suitability assessment for willow and forest } \\
\text { farming agroforestry systems in a Nebraska water- } \\
\text { shed }\end{array}$ & $\begin{array}{l}\text { Bentrup and Leininger } \\
2002\end{array}$ \\
\hline $\begin{array}{l}\text { Agroforestry Parklands in Burkina } \\
\text { Faso }\end{array}$ & GIS & $\begin{array}{l}\text { Spatial analysis of dynamics of agroforestry park- } \\
\text { lands and species distribution due to human impacts }\end{array}$ & $\begin{array}{l}\text { Bernard and } \\
\text { Depommier } 1997\end{array}$ \\
\hline $\begin{array}{l}\text { Historical Transformation of } \\
\text { Agroforestry Landscape } \\
\text { in Canada }\end{array}$ & GIS & $\begin{array}{l}\text { Spatial analysis of census and geomorphologic data } \\
\text { to explore dynamics of agroforestry in 19th century } \\
\text { Canadian landscape }\end{array}$ & $\begin{array}{l}\text { Paquette and } \\
\text { Domon } 1997\end{array}$ \\
\hline $\begin{array}{l}\text { Field-level spatial analysis of } \\
\text { temperate agroforestry system }\end{array}$ & GIS & $\begin{array}{l}\text { Spatial analysis using ground penetrating radar } \\
\text { (GPR) to evaluate root biomass and distribution } \\
\text { and soil nutrient crop-tree interactions in temperate } \\
\text { alley cropping }\end{array}$ & Jose et al. 2001 \\
\hline $\begin{array}{l}\text { AME } \\
\text { (Agroforestry Modeling } \\
\text { Environment) }\end{array}$ & Modeling Tool & $\begin{array}{l}\text { Object-oriented tool to graphically visualize, con- } \\
\text { struct, integrate and exchange agroforestry models }\end{array}$ & $\begin{array}{l}\text { Muetzelfeldt and } \\
\text { Taylor } 1997\end{array}$ \\
\hline HyPAR & Model & $\begin{array}{l}\text { Biophysical model combining crop and forest mod- } \\
\text { els and integrating climate, hydrology, light inter- } \\
\text { ception, water and nutrient competition, and carbon } \\
\text { allocation processes in agroforestry systems }\end{array}$ & Mobbs et al. 2001 \\
\hline$H y C A S$ & Model & $\begin{array}{l}\text { Biophysical model for agroforestry systems with } \\
\text { cassava simulating competition for light, water and } \\
\text { nutrients including phosphorus cycles }\end{array}$ & $\begin{array}{l}\text { Matthews and Lawson } \\
1997\end{array}$ \\
\hline
\end{tabular}


Table 3. Continued

\begin{tabular}{|c|c|c|c|}
\hline Decision support tool & Type & Description & Reference \\
\hline $\begin{array}{l}\text { WaNuLCAS } \\
\text { (Water, Nutrient and Light } \\
\text { Capture in AgroforestySystems) }\end{array}$ & Model & $\begin{array}{l}\text { Biophysical model of tree-crop interactions based } \\
\text { on above and below-ground resource capture and } \\
\text { competition of water, nutrients and light under dif- } \\
\text { ferent management scenarios in agroforestry sys- } \\
\text { tems }\end{array}$ & $\begin{array}{l}\text { Van Noordwijk and } \\
\text { Lusiana } 1999 ; \\
\text { World Agroforestry } \\
\text { Centre 2003b }\end{array}$ \\
\hline $\begin{array}{l}\text { SCUAF } \\
\text { (Soil Changes under agroforestry) }\end{array}$ & Model & $\begin{array}{l}\text { Nutrient cycling model predicts changes in soil } \\
\text { conditions under different agroforestry systems } \\
\text { based on parameters of biophysical environment, } \\
\text { land use and management, plant growth, and plant- } \\
\text { soil processes }\end{array}$ & $\begin{array}{l}\text { Young and Muraya } \\
\text { 1990; } \\
\text { Vermeulen et al. 1993; } \\
\text { Menz et al. 1997; } \\
\text { Macadong et al. 1998; } \\
\text { Nelson et al. } 1997\end{array}$ \\
\hline $\begin{array}{l}\text { FALLOW } \\
\text { (Forest, Agroforest, Low-value } \\
\text { Landscape or Wasteland?) }\end{array}$ & $\begin{array}{l}\text { Model } \\
\text { and GIS }\end{array}$ & $\begin{array}{l}\text { Model to evaluate impacts of shifting cultivation } \\
\text { and fallow rotations at a landscape-scale evaluat- } \\
\text { ing transitions in soil fertility, crop productivity, } \\
\text { biodiversity and carbon stocks }\end{array}$ & $\begin{array}{l}\text { World Agroforestry } \\
\text { Centre 2003c; } \\
\text { Van Noordwijk } 2002\end{array}$ \\
\hline $\begin{array}{l}\text { BEAM } \\
\text { (Bio-economic Agroforestry } \\
\text { Model) }\end{array}$ & Model & $\begin{array}{l}\text { Bioeconomic model to assess physical and financial } \\
\text { performance of agroforestry systems based on tree } \\
\text { and crop biometric and economic models }\end{array}$ & $\begin{array}{l}\text { Willis et al. 1993; } \\
\text { Willis and Thomas } \\
1997\end{array}$ \\
\hline $\begin{array}{l}\text { AEM } \\
\text { (Agroforestry Estate Model) }\end{array}$ & Model & $\begin{array}{l}\text { Economic model to evaluate agroforestry in com- } \\
\text { bination with other farm activities assessing ef- } \\
\text { fects of tree production and physical and financial } \\
\text { resources on-farm }\end{array}$ & $\begin{array}{l}\text { Middlemiss and } \\
\text { Knowles } 1996\end{array}$ \\
\hline $\begin{array}{l}\text { DESSAP } \\
\text { (Agroforestry Planning Model) }\end{array}$ & Model & $\begin{array}{l}\text { Multi-objective linear programming model to as- } \\
\text { sess feasible agroforestry alternatives based on } \\
\text { land, labor and cash constraints }\end{array}$ & $\begin{array}{l}\text { Garcia-de Ceca and } \\
\text { Gebremedhin } 1991\end{array}$ \\
\hline $\begin{array}{l}\text { ATK } \\
\text { (Agroforestry Knowledge Toolkit) }\end{array}$ & KBS & $\begin{array}{l}\text { KBS to store, manipulate and analyze a variety } \\
\text { of information and knowledge acquired on agro- } \\
\text { forestry systems }\end{array}$ & Walker et al. 1995 \\
\hline $\begin{array}{l}\text { AES } \\
\text { (Agroforestry Expert System) }\end{array}$ & KBS & $\begin{array}{l}\text { KBS used heuristic knowledge or expert 'rules of } \\
\text { thumb' to determine optimal species and spacing } \\
\text { for alley cropping systems in the tropics }\end{array}$ & Warkentin et al. 1990 \\
\hline $\begin{array}{l}\text { AGFADOPT } \\
\text { (Agroforestry Adoption } \\
\text { Evaluation Tool) }\end{array}$ & $\begin{array}{l}\text { Decision } \\
\text { Tree KBS }\end{array}$ & $\begin{array}{l}\text { KBS based on decision trees used to assess adop- } \\
\text { tion of agroforestry based on economic and social } \\
\text { factors faced by small-scale farmers }\end{array}$ & Robotham 1998 \\
\hline $\begin{array}{l}\text { Agroforestry Planning Tool in } \\
\text { China }\end{array}$ & $\begin{array}{l}\text { Hybrid } \\
\text { GIS, Models } \\
\text { and KBS }\end{array}$ & $\begin{array}{l}\text { Hybrid DST integrating GIS data, regression mod- } \\
\text { els plus expert knowledge to assess biophysical, } \\
\text { social and economic suitability of Paulownia inter- } \\
\text { cropping agroforestry systems }\end{array}$ & Liu et al. 1999 \\
\hline $\begin{array}{l}\text { PLANTGRO } \\
\text { (Plantation and Agroforestry } \\
\text { Species Selection Tool) }\end{array}$ & $\begin{array}{l}\text { Hybrid } \\
\text { GIS/KBS }\end{array}$ & $\begin{array}{l}\text { Plantation and agroforestry species selection tool } \\
\text { integrates GIS and expert system on plant growth }\end{array}$ & $\begin{array}{l}\text { Booth 1996; } \\
\text { Hackett and Vanclay } \\
2003\end{array}$ \\
\hline $\begin{array}{l}\text { SEADSS } \\
\text { (Southeastern Agroforestry } \\
\text { Decision Support System) }\end{array}$ & $\begin{array}{l}\text { Hybrid } \\
\text { Database, } \\
\text { GIS, KBS }\end{array}$ & $\begin{array}{l}\text { Landscape and site-scale agroforestry planning and } \\
\text { species selection DST for landowners and exten- } \\
\text { sion agents of Southeast US that integrates GIS, } \\
\text { tree and shrub database and expert knowledge }\end{array}$ & Ellis et al. 2003 \\
\hline
\end{tabular}


Table 3. Continued

\begin{tabular}{lll}
\hline Decision support tool & Type & Description \\
\hline $\begin{array}{ll}\text { Conservation Buffer Planning } \\
\text { Tools for Western Cornbelt Re- } \\
\text { gion, USA }\end{array}$ & $\begin{array}{l}\text { Hybrid } \\
\text { GIS/Models/ } \\
\text { Visualization }\end{array}$ & $\begin{array}{l}\text { Suite of GIS, economic models and visualization } \\
\text { tool for landowners and resource managers to eval- } \\
\text { uate agroforestry strategies in Midwest Cornbelt } \\
\text { region of the USA }\end{array}$ \\
\hline
\end{tabular}

ing the use and selection of agroforestry trees (Salim et al. 1998). Even though the AgroforesTree Database is recognized and linked to a variety of rural and agricultural development Websites, its specific use and impact on agroforestry research and development projects are difficult to assess at this stage.

Although not solely for agroforestry, the Forestry Compendium is an extremely useful database for agroforestry research and planning. The development of the Forestry Compendium was undertaken by both the Commonwealth Agricultural Bureau International (CABI) and International Union of Forestry Research Organizations (IUFRO) and consists of a compilation of knowledge on multipurpose forestry, including agroforestry, plantations, and natural forest management (CABI 1998; Kleine et al. 2003). The compendium gives information about what trees could be planted in a particular environment and for what purposes, how they will perform, how they should be managed, and provides current documents available regarding each species (Kleine et al. 2003). A Species Selection Module aids in decision-making for selecting suitable species according to a variety of criteria including geographical location, climate, type of use, and other management options (Kleine et al. 2003).

\section{GIS applications in agroforestry}

Considering that GIS technology is widely available and affordable today and the fact that agroforestry is directly dependent upon spatial characteristics, it is logical to expect to have several agroforestry-specific GIS DSTs; but the reality is that only a few are available. An early GIS application compiled information on 173 species including their descriptions, soil and climate preferences, and management characteristics for Africa (Booth et al. 1989). This application allowed users to query the database and generate maps showing the climatic suitability for different species. At a regional scale, Booth et al. (1990) created a similar application for Zimbabwe, demonstrating how GIS applications can be done at many scales. Unruh and Lefebvre (1995) performed a similar GIS application for sub-Saharan Africa to determine areas suitable for different agroforestry systems. Integrating ICRAF's agroforestry database with spatial data on geographic regions, climate and land uses in the region, their application was able to map out potential regions for 21 specific types of agroforestry systems.

Most of the past agroforestry GIS applications mentioned above have been research-oriented. The Southeastern Agroforestry Decision Support System (SEADSS), developed recently by the Center for Subtropical Agroforestry (CSTAF) at the University of Florida brings on-line GIS capabilities directly to extension agents and landowners; it offers county soils, land use and other spatial data for selecting suitable tree and shrub species in a specified location (Ellis et al. 2003). The USDA National Agroforestry Center (NAC) is currently using GIS to facilitate conservation buffer planning in the Western Corn Belt ecoregion in the central United States (Bentrup et al. 2000). GISguided assessments, derived from publicly available datasets, are being used to evaluate four key issues of the Western Cornbelt: biodiversity, soil protection, water quality, and agroforestry products. By combining these assessments, information is generated for use in identifying opportunities and constraints on the landscape where multiple benefits from conservation buffers, especially agroforestry plantings, can be achieved (Bentrup et al. 2000). Utilizing the agroforestry product assessments (Bentrup and Leininger 2002) in conjunction with the riparian buffer connectivity assessments, areas were identified where riparian forest buffers could be located to improve habitat connectivity while offering landowners the option to grow woody florals for profit (G. Bentrup and T. Kellerman, presentation to 8th North American Agroforestry Conference, June 2003).

GIS-guided agroforestry suitability analysis will only improve as spatial data and computer resources become more accessible. Many states and countries already are assembling internet-accessible GIS data 
Table 4. Uses, targeted end-users and current status of major decision support tools used in Agroforestry.

\begin{tabular}{|c|c|c|c|}
\hline Decision support tool & Intended use & $\begin{array}{l}\text { Targeted end- } \\
\text { users }\end{array}$ & Current status and availability \\
\hline $\begin{array}{l}\text { AFSI } \\
\text { (Agroforestry Systems } \\
\text { Inventory Database) }\end{array}$ & $\begin{array}{l}\text { General agroforestry } \\
\text { research \& planning for } \\
\text { ICRAF }\end{array}$ & $\begin{array}{l}\text { Researchers } \\
\text { and ICRAF }\end{array}$ & No current versions or availability \\
\hline $\begin{array}{l}\text { MPTS } \\
\text { (Multipurpose Tree and } \\
\text { Shrub Database) }\end{array}$ & $\begin{array}{l}\text { Species selection for agro- } \\
\text { forestry research \& planning }\end{array}$ & $\begin{array}{l}\text { Researchers } \\
\& \text { Extension } \\
\text { Agents, } \\
\text { Foresters }\end{array}$ & Upgraded to AgroforesTree \\
\hline AgroforesTree Database & $\begin{array}{l}\text { Species selection for agro- } \\
\text { forestry research \& planning } \\
\text { (World-wide) }\end{array}$ & $\begin{array}{l}\text { Researchers } \\
\& \\
\text { Fieldworkers }\end{array}$ & $\begin{array}{l}\text { CD-ROM } 1998 \text { and currently available on-line from } \\
\text { World Agroforestry Centre } \\
\text { http://www.worldagroforestrycentre.org/Sites/TreeDBS/ } \\
\text { AFT/AFT.htm }\end{array}$ \\
\hline $\begin{array}{l}\text { Subtropical Tree and } \\
\text { Shrub Database }\end{array}$ & $\begin{array}{l}\text { Species selection and in- } \\
\text { formation for agroforestry } \\
\text { extension, planning \& devel- } \\
\text { opment (American Subtrop- } \\
\text { ics \& Caribbean) }\end{array}$ & $\begin{array}{l}\text { Landowners, } \\
\text { Extension } \\
\text { Agents, } \\
\text { Researchers }\end{array}$ & $\begin{array}{l}\text { Currently under development and evaluation. Avail- } \\
\text { able on-line from Center for Subtropical Agroforestry } \\
\text { http://cstaf.ifas.ufl.edu/tree\&shrubdb.asp }\end{array}$ \\
\hline $\begin{array}{l}\text { Forestry Compendium } \\
\text { Database }\end{array}$ & $\begin{array}{l}\text { Species selection and in- } \\
\text { formation for forestry, agro- } \\
\text { forestry and plantation re- } \\
\text { search and planning and de- } \\
\text { velopment (World-wide) }\end{array}$ & $\begin{array}{l}\text { Foresters, } \\
\text { Policy } \\
\text { Makers, Con- } \\
\text { servationists, } \\
\text { Consultants, } \\
\text { Extensionists }\end{array}$ & $\begin{array}{l}\text { CD-ROM } 2003 \text { and internet version available through } \\
\text { CABI International } \\
\text { http://www.cabi.org/compendia/fc/index.asp }\end{array}$ \\
\hline $\begin{array}{l}\text { AME } \\
\text { (Agroforestry Modeling } \\
\text { Environment) }\end{array}$ & $\begin{array}{l}\text { Development of agroforestry } \\
\text { models for research }\end{array}$ & Researchers & $\begin{array}{l}\text { Now SIMILE for building general ecology models avail- } \\
\text { able from Simulistics } \\
\text { http://simulistics.com/ }\end{array}$ \\
\hline HyPAR Model & $\begin{array}{l}\text { Research on biophysical pro- } \\
\text { cess and interactions in agro- } \\
\text { forestry systems }\end{array}$ & Researchers & $\begin{array}{l}\text { HyPAR v } 4.5 \text { available through Center for Ecology and } \\
\text { Hydrology, Edinburgh, UK } \\
\text { http://www.nbu.ac.uk/hypar/ }\end{array}$ \\
\hline HyCAS Model & $\begin{array}{l}\text { Research on biophysical pro- } \\
\text { cess and interactions in cas- } \\
\text { sava agroforestry systems }\end{array}$ & Researchers & $\begin{array}{l}\text { HyCAS available through Cranfield University, UK } \\
\text { http://www.silsoe.cranfield.ac.uk/iwe/research/hycas.htm }\end{array}$ \\
\hline $\begin{array}{l}\text { WaNuLCAS Model } \\
\text { (Water, Nutrient } \\
\text { and Light Capture in } \\
\text { AgroforestrySystems) }\end{array}$ & $\begin{array}{l}\text { Research on biophysical pro- } \\
\text { cesses and interactions in } \\
\text { agroforestry systems }\end{array}$ & Researchers & $\begin{array}{l}\text { WaNuLCAS v2.11 Available through World Agroforestry } \\
\text { Centre } \\
\text { http://www.worldagroforestrycentre.org/sea/Products/ } \\
\text { AFModels/WaNulCAS/index.htm }\end{array}$ \\
\hline $\begin{array}{l}\text { SCUAF Model } \\
\text { (Soil Changes under } \\
\text { agroforestry) }\end{array}$ & $\begin{array}{l}\text { Environmental evaluation of } \\
\text { agroforestry systems used } \\
\text { for research and develop- } \\
\text { ment projects }\end{array}$ & Researchers & $\begin{array}{l}\text { SCUAF v4.0 available through Centre for Resource and } \\
\text { Environmental Studies, Australian National University } \\
\text { http://incres.anu.edu.au/imperata/imp-mods.htm }\end{array}$ \\
\hline $\begin{array}{l}\text { FALLOW Model } \\
\text { (Forest, Agroforest, } \\
\text { Low-value Landscape } \\
\text { or Wasteland?) }\end{array}$ & $\begin{array}{l}\text { Impact assessment on land- } \\
\text { scape dynamics due to so- } \\
\text { cioeconomic and land-use } \\
\text { changes }\end{array}$ & Researchers & $\begin{array}{l}\text { FALLOW available through World Agroforestry Centre } \\
\text { http://www.worldagroforestrycentre.org/sea/Products/ } \\
\text { AFModels/FALLOW/Fallow.htm }\end{array}$ \\
\hline
\end{tabular}


Table 4. Continued

\begin{tabular}{|c|c|c|c|}
\hline Decision support tool & Intended use & $\begin{array}{l}\text { Targeted end- } \\
\text { users }\end{array}$ & Current status and availability \\
\hline $\begin{array}{l}\text { BEAM } \\
\text { (Bio-economic } \\
\text { Agroforestry Model) }\end{array}$ & $\begin{array}{l}\text { Bio-economic assessment of } \\
\text { agroforestry systems used } \\
\text { for research and develop- } \\
\text { ment projects }\end{array}$ & Researchers & $\begin{array}{l}\text { Available through University of Wales, Bangor, UK } \\
\text { http://www.safs.bangor.ac.uk/ }\end{array}$ \\
\hline $\begin{array}{l}\text { AEM } \\
\text { (Agroforestry Estate } \\
\text { Model) }\end{array}$ & $\begin{array}{l}\text { Evaluation of agroforestry } \\
\text { physical and financial yields } \\
\text { for planning \& development } \\
\text { projects }\end{array}$ & Consultants & $\begin{array}{l}\text { Available through Forest Research, Rotorua, New Zealand } \\
\text { http://www.forestresearch.co.nz }\end{array}$ \\
\hline $\begin{array}{l}\text { DESSAP } \\
\text { (Agroforestry Planning } \\
\text { Model) }\end{array}$ & $\begin{array}{l}\text { Evaluation of feasibility of } \\
\text { agroforestry systems plan- } \\
\text { ning \& development }\end{array}$ & $\begin{array}{l}\text { Planners, } \\
\text { Managers, } \\
\text { Extensionists }\end{array}$ & No current versions and availability unknown \\
\hline $\begin{array}{l}\text { ATK } \\
\text { (Agroforestry } \\
\text { Knowledge Toolkit) }\end{array}$ & $\begin{array}{l}\text { Build agroforestry know- } \\
\text { ledge bases for research, } \\
\text { planning and development }\end{array}$ & $\begin{array}{l}\text { Development } \\
\text { professionals }\end{array}$ & $\begin{array}{l}\text { ATK } 5 \text { available through University of Wales, Bangor, UK } \\
\text { http://www.bangor.ac.uk/ afs } 40 \text { c/afforum/akt5/ } \\
\text { akt5_frame.htm }\end{array}$ \\
\hline $\begin{array}{l}\text { AES } \\
\text { (Agroforestry Expert } \\
\text { System) }\end{array}$ & $\begin{array}{l}\text { Alley cropping planning \& } \\
\text { Development }\end{array}$ & $\begin{array}{l}\text { Land use } \\
\text { officials, Re- } \\
\text { searchers, } \\
\text { Extensionists }\end{array}$ & No current versions and availability unknown \\
\hline $\begin{array}{l}\text { AGFADOPT } \\
\text { (Agroforestry Adoption } \\
\text { Evaluation Tool) }\end{array}$ & $\begin{array}{l}\text { Assess Agroforestry adop- } \\
\text { tion used in Dominican } \\
\text { Republic }\end{array}$ & $\begin{array}{l}\text { Researchers, } \\
\text { Planners }\end{array}$ & No current versions and availability unknown \\
\hline $\begin{array}{l}\text { PLANTGRO } \\
\text { (Plantation and } \\
\text { Agroforestry Species } \\
\text { Selection Tool) }\end{array}$ & $\begin{array}{l}\text { Species selection and land } \\
\text { use planning used for plant- } \\
\text { ation forestry planning in In- } \\
\text { donesia }\end{array}$ & $\begin{array}{l}\text { Planners, } \\
\text { Development } \\
\text { professionals }\end{array}$ & $\begin{array}{l}\text { Available through CIFOR TROPIS } \\
\text { http://www.cifor.cgiar.org/scripts/default.asp? } \\
\text { ref=research_tools/tropis/plantgro-infer.htm }\end{array}$ \\
\hline $\begin{array}{l}\text { SEADSS } \\
\text { (Southeastern } \\
\text { Agroforestry Decision } \\
\text { Support System) }\end{array}$ & $\begin{array}{l}\text { Site evaluation and species } \\
\text { selection for agroforestry } \\
\text { planning and development }\end{array}$ & $\begin{array}{l}\text { Extensionists, } \\
\text { farmers, } \\
\text { land-owners }\end{array}$ & $\begin{array}{l}\text { Currently under development } \\
\text { and available on-line from Center for Subtropical Agro- } \\
\text { forestry http://cstaf.ifas.ufl.edu/seadss.htm }\end{array}$ \\
\hline $\begin{array}{l}\text { Conservation Buffer } \\
\text { Planning Tools for } \\
\text { Western Cornbelt } \\
\text { Region, USA }\end{array}$ & $\begin{array}{lrr}\text { Facilitate } & \text { planning and } \\
\text { designing } & & \text { conservation } \\
\text { buffers } & \text { for } & \text { multiple } \\
\text { objectives } & & \end{array}$ & $\begin{array}{l}\text { Planners, } \\
\text { Landowners }\end{array}$ & $\begin{array}{l}\text { Various tools available through National Agroforestry } \\
\text { Centre } \\
\text { http://www.unl.edu/nac/conservation/index.html }\end{array}$ \\
\hline
\end{tabular}

clearinghouses to facilitate the use of spatial information.

\section{Agroforestry models}

Computer-based agroforestry models are useful for efficient handling of the many social, economic, and ecological variables that must be considered when dealing with the highly complex systems created by agroforestry. Output from these models can assist in evaluating agroforestry alternatives, testing research hypothesis, and understanding the processes and interactions in these systems, potentially saving time and money (Jagtap and Ong 1997; Muetzelfeldt and Taylor 1997). A concerted effort to start developing and implementing agroforestry models began in the mid 1990s with the Agroforestry Modeling Project (AMP). AMP was funded by the Forestry Research Programme of the UK Department of International Development and undertaken by the University of Ed- 
inburgh in association with other universities (Nottingham, Reading, North Wales and Cranfield), ICRAF and the International Institute of Tropical Agriculture (IITA). The main objectives of this project were: 1) promote liaisons between agroforestry modelers and researchers in order to add value and rigor to information obtained from experiments and models, and to improve advice given to farmers; 2) promote the integration of information obtained from agroforestry models and experiments; 3) develop process-based agroforestry models which address tree, crop and soil interaction ( $\mathrm{C}, \mathrm{N}$ and water cycles); 4) use the models to test hypotheses regarding competition between trees and crops for light, water and nutrients; and 5) define optimal agroforestry practices for different regions (Lawson and Cannell 1997).

One of the most fundamental products that came from AMP was the Agroforestry Modeling Environment (AME). Developed by Edinburgh University, AME is a tool to help visualize, construct, integrate and exchange agroforestry models. It uses a user-friendly, object-oriented environment for model construction where users can select, characterize and link predefined components and run mathematical processes (Muetzelfeldt and Taylor 1997). Users can construct models without programming by drawing model diagrams and using easily understood concepts such as 'sub-model,' 'compartment' and 'flows.' The objective of AME is to stimulate rapid model development, re-use and standardize model components developed in the past, increase the ease of building and comprehending models, and increase the efficiency and effectiveness of the modeling process (Muetzelfeldt and Taylor 1997).

Another important product that came out of AMP is the HyPAR model. It was recognized that agroforestry models needed to synthesize experimental and empirical data on tree and crop interactions; pinpoint and prioritize knowledge gaps; extrapolate research results to new combinations of soil, climate, species and management conditions; and to provide decision support to policy makers, researchers and extension staff (Mobbs et al. 2001). HyPAR combines two models: 'Hybrid,' a forest canopy model developed by the Centre for Ecology and Hydrology, and PARCH, a crop growth model developed by the University of Nottingham for application in the dry tropics. HyPAR incorporates biophysical processes to calculate light interception through a disaggregated canopy of individual types of trees in known positions along with water competition, nutrient competition, daily carbon allocation, hydrology and the impacts of different management scenarios in crop-tree agroforestry systems (Mobbs et al. 2001). A friendly, graphical user-interface guides the user input and running process with a set of menus and dialogs, allowing rapid editing of input parameters and simulation settings. In a test using a site in Ghana, the model gave validated outputs for net primary productivity in natural forest/woodland vegetation and potential sorghum grain yield. It has been shown to be useful in exploring opportunities for complementarity of light and water use by trees and sorghum in a wide variety of climates (Cannell et al. 1998; Mobbs et al. 1998).

A similar model is WaNuLCAS (Water, Nutrient and Light Capture in Agroforestry Systems), designed to model tree-soil-crop interactions for a wide range of agroforestry practices (van Noordwijk and Lusiana 1999; World Agroforestry Centre 2003b). WaNuLCAS incorporates a plant-plant interaction model focusing on above- and below-ground resource capture in a competitive situation (van Noordwijk and Lusiana 1999). The model links mulch production, its effect on soil fertility and shading effects of trees on crop yields (van Noordwijk and Lusiana 2000). The model allows different management options such as plot size, tree spacing and choice of tree species, cropping cycles, pruning, organic and inorganic fertilizer inputs and crop residue removal (van Noordwijk and Lusiana 2000).

SCUAF (Soil Changes Under Agroforestry), a nutrient cycling model that predicts annual changes in soil conditions (e.g. soil erosion, carbon, nitrogen, phosphorus and organic matter) and the effect of soil changes upon plant growth and harvest, has been used for agroforestry research since the early 1990s (Young and Muraya 1990). Research of miombo woodlands in Zimbabwe for agroforestry purposes utilized SCUAF (Vermeulen et al. 1993), as did a more recent project sponsored by the Australian Centre for International Agricultural Research (ACIAR) and the Center for International Forestry Research (CIFOR) entitled, 'Improving smallholder farming systems in Imperata areas of Southeast Asia: a bioeconomic modeling approach,' (Menz et al. 1998). For this project, SCUAF was used in the evaluation of replacing Imperata fallows with the use of Gliricidia fallows as a means to increase soil nutrient concentrations and reduce erosion (Grist et al. 1998). Magcale-Macadong et al. (1998) used SCUAF to demonstrate the use of napier grass (Pennisetum purpureum) to control soil erosion, aid productivity of hedgerow agroforestry systems by 
providing mulch, and improve livestock systems by using it as feed.

FALLOW (Forest, Agroforest, Low-value Landscape or Wasteland) is a model that scales-up the assessment of land-use systems by evaluating the impacts of shifting cultivation or crop-fallow rotations at a landscape scale (van Noordwijk 2002; World Agroforestry Centre 2003c). It can take into account a mosaic of land-use plots (100 fields) within the landscape and investigate transitions in soil fertility, crop productivity, biodiversity and carbon stocks based on the dynamics of different land-use scenarios (van Noordwijk 2002). FALLOW is unique in comparison to many other models because it considers the roles of stakeholders in transforming landscapes, as well as stakeholders' feedbacks caused by a changing landscape (van Noordwijk 2002).

The Bio-Economic Agroforestry Model (BEAM), developed by the University of Wales, predicts the physical and financial performance of agricultural monocultures and silvopastoral and agri-silvopastoral polycultures under different scenarios. Originally designed to only address poplar (Populus spp.) systems in conditions present in the United Kingdom (Willis et al. 1993), BEAM is now sufficiently generalized to allow users to predict performance under a variety of managerial, silvicultural and economic conditions (Willis and Thomas 1997). BEAM was incorporated into the ACIAR and CIFOR project mentioned earlier as a means to evaluate the bio-economic impact and interaction of rubber plantations on Imperata grass. Purnamasari et al. (2002), using a modified version of BEAM to assess the impact of Indonesian rubber production under uncertainties of prices and climate, concluded that as a risk aversion strategy, it was better to use lower planting densities, undertake longer rotations and start tapping later in the life of the trees.

Many of the models presented above, and as noted in Table 4, are complex, predominantly used by researchers, and not very friendly to the layperson. Although some have been applied outside research (for example, BEAM and SCUAF), there is little evidence of use by decision makers, planners, extension agents and landowners. While many current versions of these models can still be obtained, there has not been a notable effort of their application toward extension and planning purposes.

\section{Agroforestry knowledge-based or expert systems}

The Agroforestry Knowledge Tool Kit (AKT) is perhaps the best initial attempt so far to construct and develop a 'true' KBS applicable to agroforestry (Walker et al. 1995). Recognizing the dearth of quantitative data in agroforestry and the need to consider a variety of information from a multidisciplinary range of sources (including farmers), AKT provides a framework to synthesize heuristic knowledge related to agroforestry systems and their ecological dynamics. AKT applies a formal language representation system to store and link together knowledge collected from different sources, which users, by using diagrams or a text-based interface, can access and infer the knowledge base in a flexible manner. Inferences on the knowledge base are especially useful in detecting gaps in the knowledge base and in extracting information for extension and planning purposes. Its application in representing temporal and spatial aspects of agroforestry, however, is limited (Walker et al. 1995).

AKT's use by researchers and development professionals includes the development of knowledge bases for agroforestry systems in South Asia, Southeast Asia and Africa, such as tree-fodder systems in Nepal, fermented tea production in the hills of Thailand, rangeland management with trees in Tanzania, and the Kandy forestry gardens in Sri Lanka. During 2001, ICRAF and the University of Wales conducted workshops for research institutions and NGOs (nongovernmental organizations) in Thailand on the value of local ecological knowledge using the current AKT-5 (World Agroforestry Centre 2003d). Currently ATK is being used for various projects funded by the United Kingdom Department for International Development (DFID) (Dixon et al. 2001).

\section{Hybrids and combination decision-support tools}

Many DSTs used in agroforestry involve the use and integration of several different types of computerbased technologies. In China, a knowledge-based model developed for regional agroforestry planning of Paulownia-crop intercropping (PCI) integrates GIS, regression models and expert knowledge in order to spatially determine the biophysical, social and economic suitability of PCI within a planning area landscape (Liu et al. 1999).

CSTAF's SEADSS mentioned earlier is developed to address agroforestry problems at various scales (site 


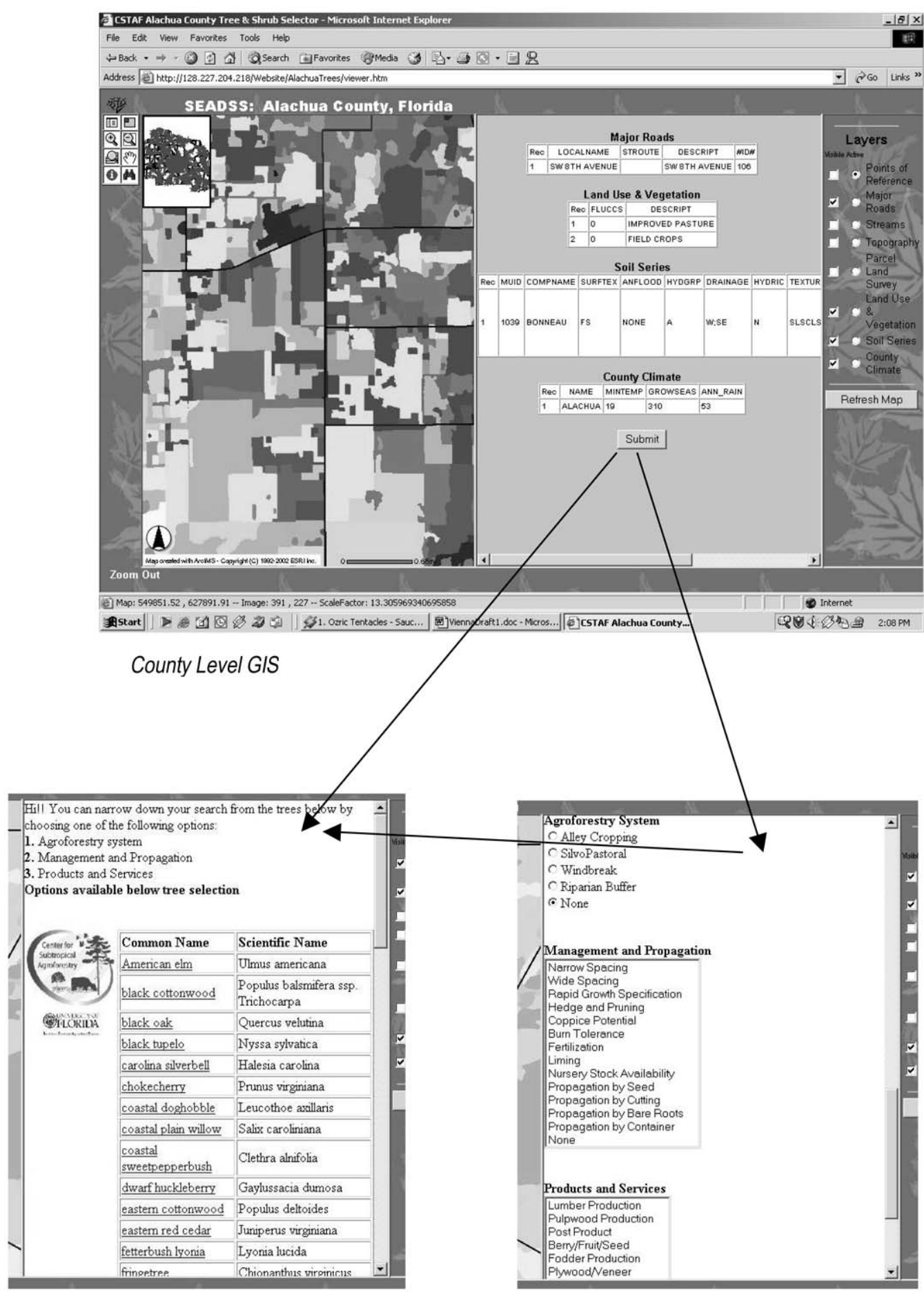

Tree and Shrub Database

Expert Knowledge for Agroforestry Planning

Figure 1. Hybrid decision support tool integrating GIS, sub-tropical tree and shrub database, and expert knowledge for agroforestry species selection in southeastern counties. Source: Ellis et al. 2003. 
and landscape) and for different purposes (farm production and rural sustainability). It is an on-line hybrid DST linking county-level GIS, a subtropical tree and shrub database and expert knowledge to evaluate suitable tree or shrub components for specific sites and agroforestry practices (Ellis et al. 2003) (Figure 1). SEADSS selects trees from the database using queries that take into account climate and soil parameters from a selected geographic site and management criteria. Expert knowledge incorporated into SEADSS's database queries was obtained by surveying agroforestry professional using questionnaires to determine the following: 1) desired morphological and habit characteristics of species for each agroforestry practice, 2) economic and environmental services obtained from an agroforestry system, and 3) optimal plant characteristics for different environmental services (e.g. erosion control) (Ellis et al. 2000). SEADSS's intended end-users are landowners and extension agents, and their inputs and participation are essential during the validation and evaluation process.

Researchers and technology transfer experts at the USDA National Agroforestry Center and the University of Missouri recognized the need for a diverse range of DSTs to accommodate each unique setting in which agroforestry may be applied. Their Conservation Buffer Planning Project is developing a variety of DSTs (e.g., GIS-guided assessments, visual simulations, and cost-benefit models) to address the biophysical, social and economic issues critical in the planning and designing of systems that can better balance production with environmental stewardship (Figure 2) (Bentrup et al. 2000). The diversity of DSTs incorporated into this project reflects the need to meld concerns and objectives that occur at various spatial scales, the variability of information that may be available, and the recognition that people are differentially influenced in a decision-making process.

\section{Challenges and opportunities for agroforestry decision-support tools}

The major challenge in the development of effective computer-based DSTs for agroforestry is dealing with its complex nature. This challenge is further exacerbated by the limited knowledge base we have to work with currently and the many unresolved issues, making the decision process in agroforestry planning even more complex. Regardless of this challenge, the need for these tools is becoming more imperative, especially for extension and planning activities.

\section{From databases to GIS and knowledge bases}

DSTs incorporating databases are extremely valuable in organizing and accessing data and information. A database inventorying and describing agroforestry systems, such as AFSI, is extremely valuable and has great potential to be integrated into a GIS to evaluate the spatial distribution, characteristics and species components of agroforestry systems throughout the world. To ensure usability, databases need to be developed, tested and evaluated with end-user involvement. Up-front participation by end-users will result in better matching the tool to the end-user's needs and capabilities, and in increasing the awareness and therefore subsequent use of the tool by the end-user groups. The greater the utility for and use by end-users, the greater the support to maintain its utility and use over time. For example, AFSI has not been upgraded and does not appear to be used.

Descriptive and biophysical data for a majority of species are still unknown, making it difficult to develop useful databases. For instance, much of the early research on agroforestry species has concentrated on the aboveground productivity and has paid little attention to belowground issues such as, root characteristics and root responses to management practices (Sinclair 1996). As new pertinent information becomes available, databases will need to be updated to maintain their value and future utility. Database developers will therefore need to consider potential mechanisms for maintaining and upgrading their database. For example, AgroforesTree is both maintained and available on-line, making it more popular than its predecessor (MPTS).

Although the adoption of GIS applications has been slow in agroforestry research and planning, this trend is changing as a greater variety of spatial data is becoming accessible and affordable. Data on soils and land use are often free, and remotely sensed images (aerial photographs and satellite imagery) are also now available free or at very low costs. As GIS technology continues to become cheaper and easier to use, integrating agroforestry databases with geo-referenced data will occur due to the spatial nature and landscape issues involved with agroforestry planning and development. Users of this technology may not even be required to have GIS software and hardware with the advent of on-line GIS applications like SEADSS, 


\section{Regional Atlas}

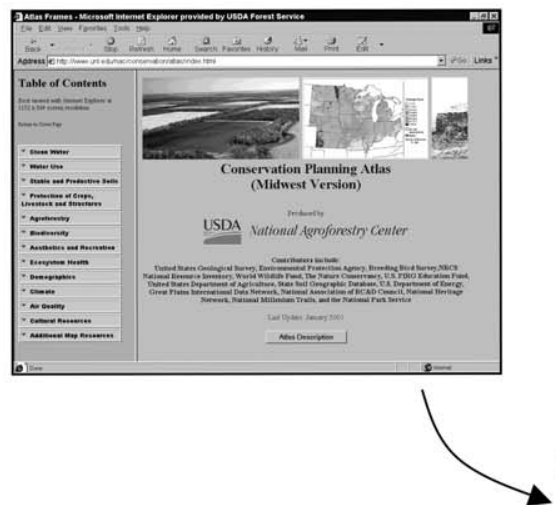

Regional Scale Reconnaissance
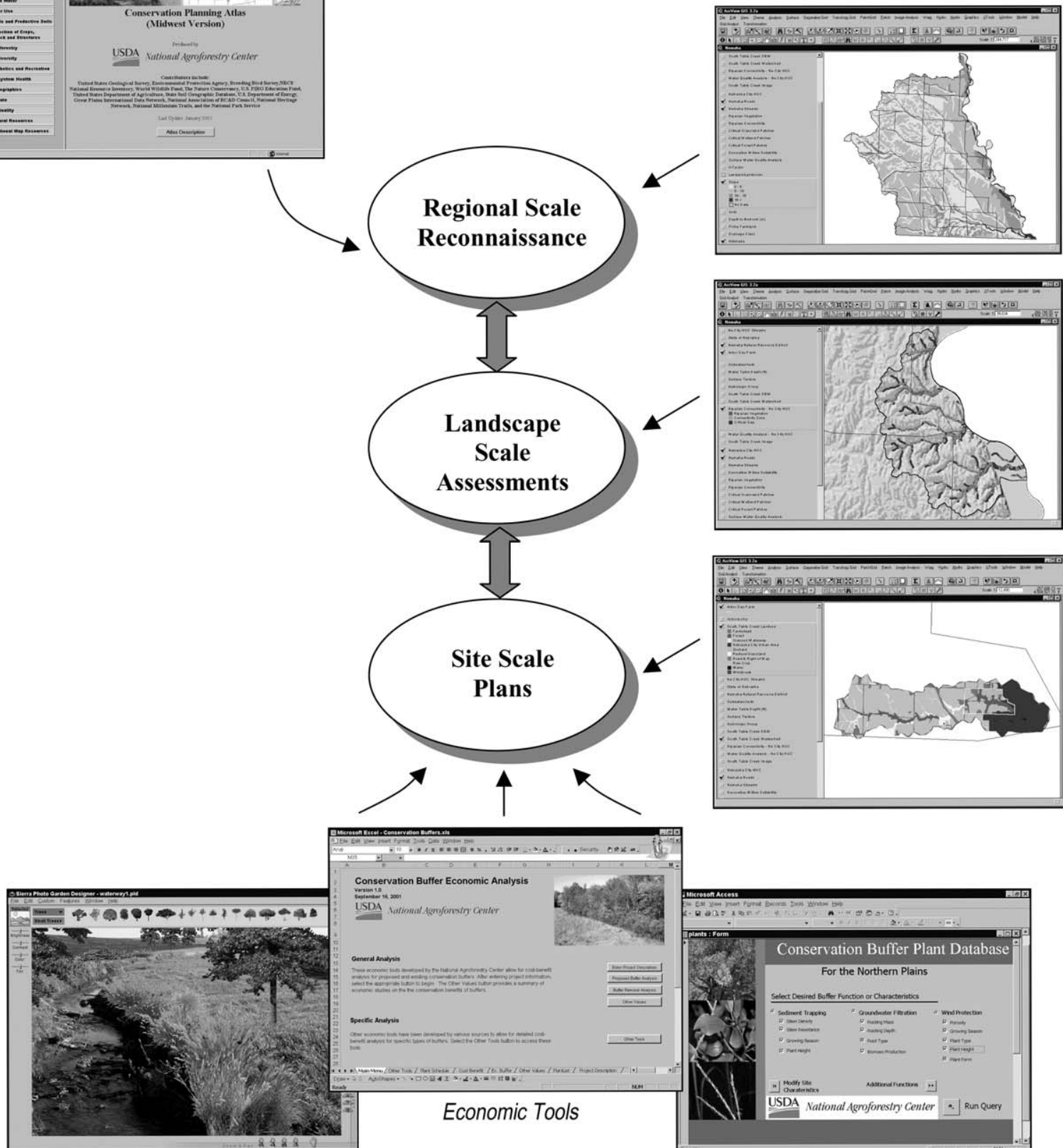

Visualization Tools
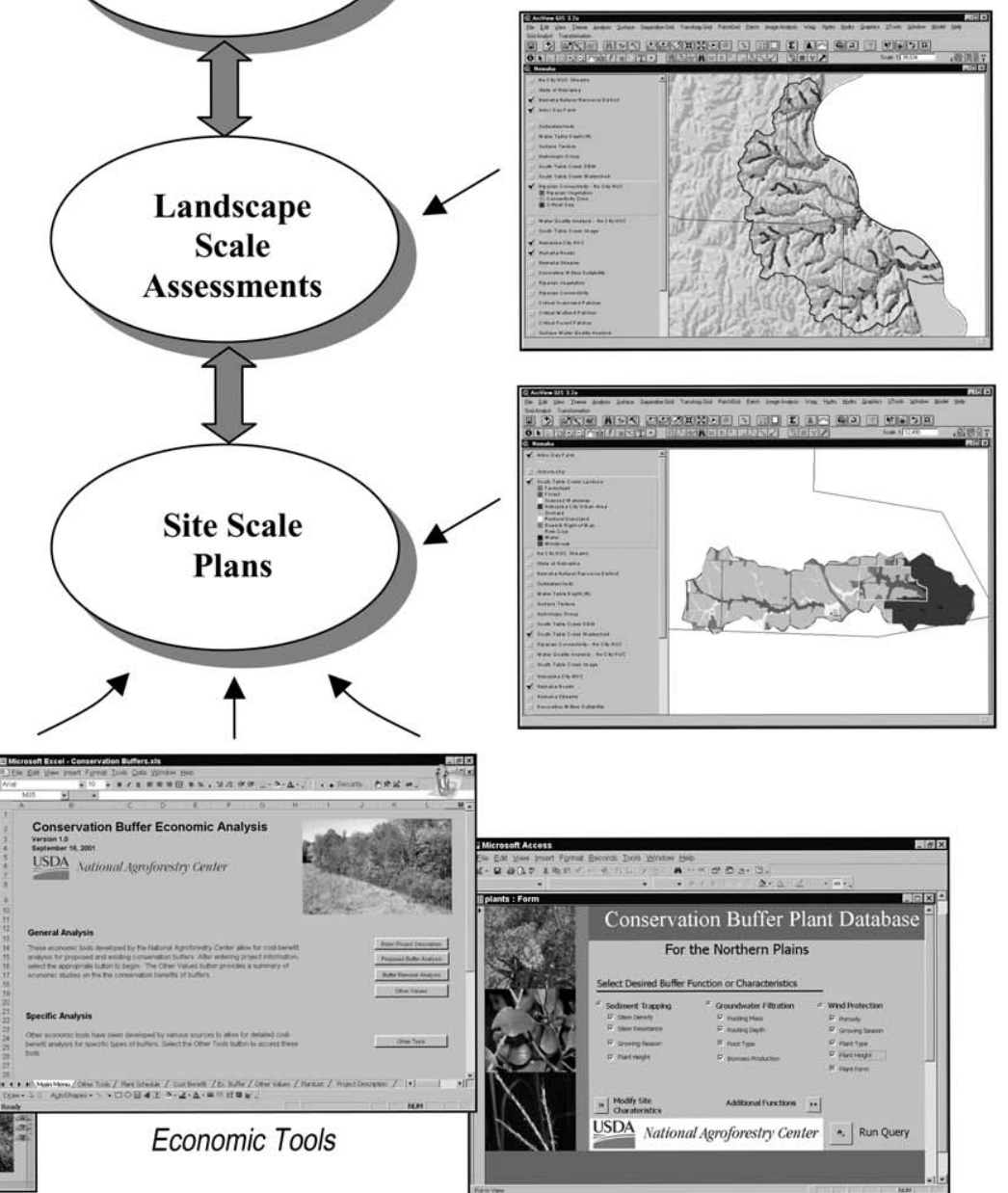

Plant Selection Guide

Figure 2. Suite of computer-based tools being developed for a multi-scale and multi-issue conservation planning process for agroforestry buffers in the Western Corn-belt Ecoregion (Bentrup et al. 2000). 
for example, which offers county-level GIS to extension agents and landowners within a user-friendly interface.

Knowledge-Based Systems have value because effective decision-making in agroforestry must involve the use of all available scientific, professional, and traditional information and knowledge. Currently much of our agroforestry knowledge is incomplete, contentious, observational, and qualitative. KBS overcomes some of these problems by tying these diverse sets of information together for the purposes of evaluating and synthesizing qualitative and traditional knowledge in addition to conventional research on agroforestry practices and systems (Sinclair and Walker 1998; Walker and Sinclair 1998; Dixon et al. 2001). Dixon et al. (2001) list some examples of reasoning tasks that knowledge bases could provide, including 1) generating synthesized reports on the current state of knowledge for a specific topic, 2) exploring the knowledge base to identify discrepancies between scientifically and locally derived knowledge, 3 ) correlating scientific information with professional and traditional knowledge, and 4) identifying key gaps in understanding agroforestry topics and practices.

\section{From models to hybrid and combined decision-support tools}

Much effort has focused on building sophisticated agroforestry models for research. Jagtap and Ong (1997) suggest that the ultimate goal of modeling should be to increase the relevance and efficiency of research by integrating the major social, economic and biophysical driving forces influencing agroforestry practices. They have identified several areas still in need of research that they feel are necessary for the development of efficient and successful models, including below-ground interactions, root architecture and dynamics, organic matter turnovers, nutrient and water competition, and livestock grazing on agroforestry practices. One potential result of these modeling efforts will be whole-farm evaluations that assess the suitability of agroforestry options to meet landowner and societal expectations of the land. In addition, models should be linked to GIS to predict where and how agroforestry technologies might be used; facilitating research and development, technology transfer, and policy and program activities (Bentrup and Leininger 2002).

Many of the models developed to-date have proved to be difficult to use for many practitioners, requiring large sets of specific parameter information that are frequently unavailable. As a result, some models have been hard to use for environments different than those in which they were originally developed, creating frustration among potential users of the models. While this highlights the need to collect additional and standardized data on crop, tree, soil and climate parameters for different geographical regions, it also clearly demonstrates the need to link the models with users' needs and resources.

Due to the variety and complexity of computerbased tools, agroforestry researchers and practitioners will need to partner with experts in computer science to develop effective and efficient DSTs (Walker and Lowes 1997). Through the development and evaluation of DSTs, knowledge gaps and future research needs can be determined. As with any innovative technology, agroforesters must be careful, however, not to view the DSTs as the ends but as a means to assist decision-making. As Wu and Hobbs (2002) state, 'We need to avoid having powerful methodologies in search of meaningful questions to answer; rather we need to seek the right techniques to answer pressing questions.'

\section{Future direction for DST development in agroforestry}

To place this review into the larger context of decision support, we need to step back from the specifics of the technology. Critical up-front questions need to be addressed as computer-based DSTs are being developed:

What is the primary purpose of DSTs?

What issues will the DSTs address?

Who will be the end-users of DSTs?

Who will develop the DSTs?

Who will implement/maintain the DSTs after development?

As mentioned earlier, many of the DSTs developed for agroforestry systems to-date are for testing research hypotheses. The tools primarily explore and evaluate the multitude of biophysical parameters for determining the key interrelationships in agroforestry practices. Developed primarily for research purposes, these tools play a valuable role in building the scientific foundation of agroforestry and will continue to be an important area of focus. On the other hand, development of DSTs for the adoption, planning, and implementation of agroforestry practices is vastly 
lacking in comparison to research-based applications. Developers of research-based tools often make the assumption that their applications can be easily used in the planning and design process of agroforestry systems. The answers to the critical questions guiding tool development, specifically, what is needed to influence end-user decision making, are more often than not different in research and planning-driven applications. The primary purpose for tools in research is to address the why of agroforestry practices, whereas in the planning and design process, the focus is on the what, where and how.

Because of the time and cost involved in the development of DSTs, they should be targeted to match end-user's needs and resources (Robinson 1996). Users of agroforestry tools for planning and design are primarily landowners and resource professionals working together in partnership to develop agroforestry plans. In this case, when the end-users are not directly involved in the development process, the result will be ineffective tools that do not respond to users' problems and needs, creating a waste of project funds and bitter feelings between developers and users (Hoag et al. 2000, Turner and Church 1995).

DSTs for research by necessity tend to focus on a limited number of issues while landowners must necessarily incorporate numerous and diverse issues in their decision-making process on whether or not to adopt agroforestry practices (Walker and Lowes 1997). Due to each individual's unique situation, resources, and personal value system, these biophysical, economic, and social issues are weighted differently in every potential application of agroforestry. The DSTs we create for agroforestry planning and design must be flexible enough to accommodate the range of potential issues and each individual unique decision-making process. Again, due to the nature of these issues, they need to be analyzed and synthesized at a variety of spatial scales. For instance, Helenius (1995) points out the advantages of being able to plan for ecological pest management at the landscape level where 'the benefits of improved logistics and economy of scale may provide sufficient incentive for the necessary local cooperation between farmers.'

Because one DST will not satisfy all of these demands, a suite of tools must be created to address the variety of issues at multiple scales. Ideally, these should be loosely coupled rather than intricately woven together. This approach allows users to select the DSTs appropriate for their situation and it facil- itates the integration of new tools into the planning process.

From this brief discussion, several important principles are listed that can serve as a starting point for developers embarking on tool development. The DSTs should be:

- Focused on the what, where and how

- Capable of addressing multiple issues

- Developed with user participation

- Suitable for multiple spatial scales

- A loosely coupled suite of tools, and be

- Amenable to standardization of data formats.

Several projects illustrate some of these principles. SEADSS, for example, is working with landowners and extension agents to develop an online GIS application for plant selection at site and landscape scales (Ellis et al. 2003). The Comprehensive Conservation Buffer Planning Project offers a suite of loosely coupled DSTs for simultaneously addressing multiple issues across multiple scales (Bentrup et al. 2000). This project is also expanding the traditional definition of DSTs used in agroforestry by broadly considering the landowner adoption process. One such category of tools is computer-based visual simulations that can graphically depict future agroforestry scenarios at various spatial and temporal scales. This enables landowners and other stakeholders to better conceptualize and understand the agroforestry alternatives and it seems to be more influential in landowner/stakeholder adoption than information generated by ecological or economic DSTs (Al-Kodmany 1999; Nassauer et al. 2001).

Successful application of agroforestry systems depends upon pulling together diverse sources of information, in a manner that responds to users' needs and resources. Computer-based DSTs that accommodate these tasks can greatly facilitate the decision-making process that seeks to simultaneously balance environmental and production goals that meet landowner and societal needs. As Nassauer et al. (2001) state, we must go beyond providing tools that only address the ecological and economic aspects of sustainability and provide those that also enhance the cultural sustainability of agroforestry systems; that is, it must elicit sustained human attention over time or else the benefits may be compromised as land ownership changes, as development pressure increases, or as different political viewpoints arise. 


\section{Acknowledgements}

Florida Agricultural Experiment Station Journal Series Number R-09865. This publication was partially supported by U.S. Department of Agriculture, Cooperative State Research, Education, and Extension Service, Initiative for Future Agriculture and Food Systems (USDA/CSREES/IFAFS) grant number 0052103-9702. This paper was written and prepared by a U.S. government employee on official time, and therefore it is in the public domain and not subject to copyright.

\section{References}

Acock B., Pachepsky Y.A., Acock M.C., Reddy V.R. and Whisler F.D. 1997. Modeling soybean cultivar development rates using field data from the Mississippi Valley. Agron J 89: 994-1002.

Ahuja L.R., Ma L., Howell T.A. 2002. Agricultural System Models in Field Research and Technology Transfer. Lewis Publishers. Boca Raton, FL, 357 pp.

Al-Kodmany K. 1999. Using visualization techniques for enhancing public participation in planning and design: process, implementation, and evaluation. Landscape Urban Plan 45: 37-45.

Bentrup G., Dosskey M., Schoeneberger M., Wells M., Leininger T. and Klenke K. 2000. Planning for multi-purpose riparian management. pp. 423-426. In: Wigington P.J. and Beschta R.L. (eds), Riparian Ecology and Management in Multi-Land Use Watersheds. American Water Resources Association, Middleburg, VA.

Bentrup G. and Leininger T. 2002 Agroforestry mapping: the way GIS. J Soil Water Conserv 57: 148-153.

Bernard C. and Depommier D. 1997. The systematic approach and the role of GIS in the characterization and monitoring of agroforestry parks. XI World Forestry Congress, Antalya, Turkey, 13 to 22 October 1997, Vol. 1., p. 87.

Boote K.J., Jones J.W. and Hoogenboom G. 1998a. Simulation of crop growth: CROPGRO Model. pp. 651-692. In: Peart R.M. and Curry R.B. (eds), Agricultural Systems Modeling and Simulation. Marcel Dekker, New York, NY.

Boote K.J., Jones J.W., Hoogenboom G. and Pickering N.B. 1998b. The CROPGRO model for grain legumes. pp. 99-128. In: Tsuji G.Y., Hoogenboom G. and Thornton P.K. (eds), Understanding Options for Agricultural Production. Kluwer Academic Publishers, Dordrecht, The Netherlands.

Booth T.H. 1996. Tree selection and growth improvement. pp. 311316. In: Dieters M.J., Matheson A.C., Nikles D.G., Hardwood C.E. and Walker S.M. (eds), Tree Improvement for Sustainable Tropical Forestry: Proceedings of OFRI-IUFRO Conference. Queensland Forestry Research Institute. Gypie, Qld, Australia.

Booth T.H., Stein J.A., Nix H.A. and Hutchinson M.F. 1989. Mapping regions climatically suitable for particular species: an example using Africa. Forest Ecol Manag 28: 19-31.

Booth T.H., Stein J.A., Hutchinson M.F. and Nix H.A. 1990. Identifying areas within a country climatically suitable for particular tree species: an example using Zimbabwe. Int Tree Crops J 6: $1-16$.

Bydekerke L., Van Ranst E., Vanmechelen L. and Groenemans R. 1998. Land suitability assessment for cherimoya in southern
Ecuador using expert knowledge and GIS. Agric Ecosys Environ 69: 89-98.

Cannell M.G.R., Mobbs D.S. and Lawson G.J. 1998. Complementarity of light and water use in tropical agroforests II. Modelled theoretical tree production and potential crop yield in arid to humid climates. Forest Ecol Manag 102: 275-282.

CABI (Commonwealth Agricultural Bureau International) 1998. The Forestry Compendium: A Silvicultural Reference. CABI, Oxford, United Kingdom. CD-ROM.

Davis M.W. 1988. Applied Decision Support. Prentice-Hall, Englewood Cliffs, NJ. 256 pp.

De Mers M.N. 1997. Fundamental of Geographic Information Systems. Wiley, New York, $486 \mathrm{pp}$.

Dixon H.J., Doores J.W., Joshi L. and Sinclair F.L. 2001. Agroecological Knowledge Toolkit For Windows: Methodological Guidelines, Computer Software and Manual for AKT5. School of Agricultural and Forestry Sciences, University of Wales, Bangor UK, $171 \mathrm{pp}$.

Dosskey M. and Wells G. 2000. Planning agroforestry practices. Agroforestry Notes (AF) \#20. USDA National Agroforestry Center, 4 pp.

Easterling W.F., Hays C.J. Easterling M.M. and J.R. Brandle J.R. 1997. Modeling the effect of shelterbelts on maize productivity under climate change: an application of the EPIC model. Agric Ecosys Environ 61: 163-176.

Ellis E.A., Nair P.K.R., Linehan P.E., Beck H.W., Blanche C.A. 2000. A GIS-based database management application for agroforestry and tree selection. Computers and Electronics in Agriculture. 27: 41-55.

Ellis E.A., Nair P.K.R. and Jeswani S.D. 2003. The southeastern agroforestry decision support system (SEADSS): a Web-based application for agroforestry planning and tree selection. pp. 112. In: Vacik H., Lexer M.J., Rauscher M.H., Reynolds, K.M. and Brooks R.T. (eds), Decision Support for Multiple Purpose Forestry. A Transdisciplinary Conference on the Development and Application of Decision Support Tools for Forest Management. 23-25 April 2003, University of Natural Resources and Applied Life Sciences, Vienna Austria, CD-ROM.

Field R.C. 1984. National forest planning is promoting US Forest Service acceptance of operations research. Interfaces 14: 67-76.

Garcia-de-Ceca J.L. and Gebremedhin K.G. 1991. A decision support system for planning agroforestry systems. Forest Ecol Manag 45: 199-206.

Gertsis A.C. and Whisler F.D. 1998. GOSSYM: a cotton crop simulation model as a tool for the farmer. Acta Horticulturae. 476: 213-217.

Grabaum R. and Meyer B. 1998. Multicriteria optimization of landscapes using GIS-based functional assessments. Landscape Urban Plan 43: 21-34.

Grist P., Menz K. and Nelson R. 1998. Gliricidia as improved fallow. pp. 133-148. In: Menz K.M., Magcale-Macandog D. and Rusastra W.I. (eds), Improving Smallholder Farming systems in Imperata Areas of Southeast Asia: Alternatives to Shifting Cultivation. ACIAR Monograph No. 52.

Guo Q. 2000. Climate change and biodiversity conservation in the Great Plains. Global Environmental Change 10: 289-298.

Hackett C. and Vanclay J.K. 2003. Mobilizing expert knowledge of tree growth with the PLANTGRO and INFER systems. Plantsoft Services, Stirling Australia and CIFOR, Jakarta, Indonesia, $18 \mathrm{pp}$.

Helenius J. 1995. Regional crop rotation for ecological pest management (EPM) at landscape level. pp. 255-260. In: Integrated Crop Protection: Towards Sustainability? Proceedings of the British 
Crop Protection, 1995, September 11-14, Edinburgh, Scotland. BCPC Registered Office, Surrey, UK.

Hoag D.L., Ascough II J.C. and Frasier W.M. 2000. Will farmers use computers for resource and environmental management? J Soil Water Conserv 55: 456-462.

Jagtap S. and Ong C.K. 1997. Perspective on issues, needs and opportunities for agroforestry models. pp. 110-112. In: Agroforestry Modelling and Research Coordination. Annual Report to ODA July 1996-June 1997. Institute of Terrestrial Ecology. Natural Environment Research Council. Edinburgh, UK.

Jones C.A., Dyke P.T., Williams J.R., Kiniry J.R., Benson V.W., Griggs R.H. 1991. EPIC: and operational model for evaluation of agricultural sustainability. Agr Syst 37: 341-350.

Jones J.W., Tsuji G.Y., Hoogenboom G., Hunt L.A., Thornton P.K., Wilkens P.W., Imamura D.T., Bowen W.T. and Singh U. 1998. Decision support system for agrotechnology transfer; DSSAT v3. pp. 157-177. In: Tsuji G.Y., Hoogenboom G. and Thornton P.K. (eds), Understanding Options for Agricultural Production. Kluwer Academic Publishers, Dordrecht, The Netherlands.

Jones J.W., Hoogenboom G., Poter C.H., Boote K.J., Batchelor W.D., Hunt L.A., Wilkens P.W., Singh U., Gijsman A.J. and Ritchie J.T. 2003. The DSSAT cropping system model. Eur J Agron 18: 235-265.

Jose S., Gillespie A.R., Seifert J.R. and Pop P.E. 2001. Comparison of minirhizotron and soil core methods for quantifying root biomass in a temperate alley cropping system. Agroforest Syst 52: 161-168.

Kent B., Bare B.B., Field R.C. and Bradley G.A. 1991. Natural resource land management planning using large scale linear programs: the USDA Forest Service experience with FORPLAN. Oper Res 39: 13-27.

Kleine M., Scott P., de Neergard N.B., Pasiecznik N. and Becker K. 2003. New technologies to support decision making and global collaboration in multiple-purpose forest managementthe Forestry Compendium and the Global Forest Information System. pp. 1-10. In: Vacik H., Lexer M.J., Rauscher M.H., Reynolds K.M. and Brooks R.T. (eds), Decision Support for Multiple Purpose Forestry. A Transdisciplinary Conference on the Development and Application of Decision Support Tools for Forest Management. April 23-25, 2003, University of Natural Resources and Applied Life Sciences, Vienna Austria, CD-ROM

Knopp P.D. and Twery J. 2003. Stewplan: software for creating forest stewardship plans (Version 1.3). Gen. Tech. Rep. NE-301. U.S. Department of Agriculture, Forest Service, Northeastern Research Station, 12 pp.

Lacher T.E. 1998. The spatial nature of conservation and development. pp. 3-12. In: Savitsky B.G. and Lacher T.E. (eds), GIS Methodologies for Developing Conservation Strategies: Tropical Forest Recovery and Wildlife Management in Costa Rica. Columbia University Press, New York, NY.

Lawson G.J. and Cannell M.G.R. 1997. Introduction and Formal DFID Annual Progress Report. pp. 1-9. In: Modelling and Research Coordination. Annual Report to ODA July 1996June 1997. Institute of Terrestrial Ecology. Natural Environment Research Council. Edinburgh, UK.

Liebowitz J. 1990. The Dynamics of Decision Support Systems and Expert Systems. Dryden Press, Chicago. 211 pp.

Liu J., Shao G. and Li W. 1999. Expert knowledge-based model for regional agroforestry planning. pp. 1-8. In: Li B Geoinformatics and Socioinformatics: The Proceeding of Geoinformatics' 99 Conference. Ann Arbor, Michigan, 19-21 June. University of California, Berkely, CA.
Loh D.K. and Rykiel E.J. 1992. Integrated resource management systems: coupling expert systems with data-base management and geographical information systems. Environ Manage 16: 167-177.

Magcale-Macadong D.B., Predo C.D., Menz K.M. and Calub A.D. 1998. Napier grass strips and livestock: a bioeconomic analysis. Agroforest Syst 40: 41-58.

Manning E. 1996. GLYCIM: crop model for soybeans. Progressive Farmer 11: 33.

Masera O.R., Garza-Caligaris, J.F., Kanninen M., Karjalainen T., Liski J., Nabuurs G.J., Pussinen A., de Jong B.H.J., Mohren G.M.J 2003. Modeling carbon sequestration in afforestation, agroforestry, and forest management projects: the CO2FIX V.2 approach. Ecol Mod 164: 177-199.

Mata-Toledo R.A. and Cushman P.K. 2000. Schaum's Outline of Fundamentals of Relational Database. McGraw-Hill Professional. New York, NY. 249 pp.

Matthews, R.B. and Lawson G.J. 1997. Structure and applications of the HyCAS model. Agroforest Forum 8(2): 14-17.

Menz K.M., Magcale-Macandog D. and Rusastra W.I. (eds) 1998. Improving Smallholder Farming Systems in Imperata areas of Southeast Asia: Alternatives to Shifting Cultivation. ACIAR Monograph No. $52.280 \mathrm{pp}$

Middlemiss P. and Knowles L. 1998. AEM Agroforestry Model User Guide for v.4.0g. Forest Research Institute, Rotorua, New Zealand. $121 \mathrm{pp}$.

Mobbs D.C., Cannell M.G.R., Crout N.M.J., Lawson G.J., Friend A.D., Arah J. 1998. Complementarity of light and water use in tropical agroforests I. Theoretical model outline, performance and sensitivity. Forest Ecol Manag 102: 259-274.

Mobbs D.C., Lawson G.J., Brown T.A.W. 2001. Model for Agroforestry Systems User Guide: HyPAR Version 4.1. Centre for Ecology \& Hydrology, Forestry Research Programme. Edinburgh, UK. $52 \mathrm{pp}$.

Muetzelfeldt R.B. and Taylor J. 1997. The Agroforestry Modelling Environment. pp. 10-20. In: Agroforestry Modelling and Research Coordination. Annual Report to ODA July 1996June 1997. Institute of Terrestrial Ecology. Natural Environment Research Council. Edinburgh, UK.

Nair P.K.R. 1987. Agroforestry System Inventory. Agroforest Syst 5: 319-338.

Nair P.K.R. 1998. Directions in tropical agroforestry research: past, present and future. Agroforest Syst 38: 223-245.

Nair P.K.R. 2001. Agroforestry. pp. 375-393. In: Our Fragile World: Challenges and Opportunities for Sustainable Development, Forerunner to The Encyclopedia of Life Support Systems, Chapter 1.25, vol. I. UNESCO, Paris, France, \& EOLSS, UK.

Nassauer JI, Kosek SE and Corry RC. 2001. Meeting public expectations with ecological innovation in riparian landscapes. $\mathrm{J}$ American Water Resources Association 37: 1439-1443.

NRC (National Research Council). 1997. Precision Agriculture in the 21st Century: Geospatial and Information Technologies in Crop Management. National Academy Press, Washington, D.C. $149 \mathrm{pp}$.

Nelson R.A., Grist P.G., Menz K.M., Cramb R.A., Paningbatan E.P. and Mamicpic M.A. 1997. A cost-benefit analysis of hedgerow intercropping in the Philippine uplands using the SCUAF model. Agroforest Syst 35: 203-220.

Nikolopoulos C. 1997. Expert Systems: Introduction to First and Second Generation and Hybrid Knowledge Based Systems. Marcel Dekker, New York. 331 pp.

Oduol .P.A., Muraya P., Fernandes E.C.M. and Nair P.K.R. 1988 The agroforestry systems database at ICRAF. Agroforest Syst 6: 253-270. 
Paarlberg D. and Paarlberg P. 2000. Agricultural Revolution of the 20th Century. Iowa State University Press, Ames, IA. 154 pp.

Paquette S. and Domon G. 1997. The transformation of the agroforestry landscape in the nineteenth century: a case study in southern Quebec, Canada. Landscape Urban Plan 37: 197-209.

Patterson D.W. 1990. Introduction to Artificial Intelligence and Expert Systems. Prentice-Hall, Englewood Cliffs, NJ. 448 pp.

Peng G., Leslie L.M., Shao Y. 2002. Environmental Modelling and Prediction. Springer-Verlag. Berlin, Germany. 480 pp.

Purnamasari R., Cahco O. and Simmons P. 2002. Management strategies for Indonesian rubber production under yield and price uncertainty: a bioeconomic analysis. Agroforest Syst 54: 121-135.

Rauscher M.H. 1999. Ecosystem management decision support for federal forests in the United States: a review. Forest Ecol Manag 114: 173-197.

Reddy K.R., Kakani V.G., McKinion J.M. and Baker D.N. 2002. Applications of a cotton simulation model, GOSSYM, for crop management, economic and policy decisions. pp. 33-54. In: Ahuja L.R., Ma L. and Howell T.A. (eds), Agricultural System Models in Field Research and Technology Transfer. Lewis Publishers. Boca Raton, FL.

Reynolds K.M., Rodriguez S. and Bevans K. 2002. Ecosystem Management Decision Support. USDA Forest Services, Pacific Northwest Station. Corvallis, OR. 80 pp.

Ritchie J.T. and Otter S. 1985 Description and performance of CERES-Wheat: a user oriented wheat yield model. pp. 159175. In: ARS Wheat Yield Project. ARS 38. National Technical Information Service, Springfield, VA.

Robinson B. 1996. Expert systems in agriculture and long-term research. Canadian J Plant Science 76: 611-617.

Robotham M.P. 1998. AGFADOPT: a decision support system for agroforestry project planning and implementation: pp. 167-176. In: El-Swaify S.A. and Yakowitz D.S. (eds), Multiple Objective Decision Making for Land, Water and Environmental Management: Proceedings of the First International Conference on Multiple Objective Decision Support Systems for Land, Water and Environmental Management: Concepts, Approaches, and Applications. Lewis, Boca Raton, FL.

Ruark G.A., Schoeneberger M.M. and Nair P.K.R. 2003. Agroforestry - Helping to Achieve Sustainable Forest Management. UNFF (United Nations Forum for Forests) Intersessional Experts Meeting on the Role of Planted Forests in Sustainable Forest Management, 24-30 March 2003, New Zealand. pp. 1-13.

Salim A.S., Simons A.J., Waruhiu A., Orwa C. and Anyango C. 1998. Agroforestry Database: A Tree Reference and Selection Guide. Version 1.0. ICRAF. Nairobi, Kenya. CD-ROM.

Sanchez P.A. 1995 Science in agroforestry. Agroforest Syst 30: 555.

Sanders R.E. (2000) DB2 Universal Database: Application Programming Interface (API) Developer's Guide. McGraw-Hill Professional. New York, NY. 640 pp.

Schmoldt D.L. and Rauscher H.M. 1996. Building KnowledgeBased Systems for Natural Resource Management. Chapman \& Hall, New York. 386 pp.

Schoeneberger M., Dix M. and Dosskey M. 1994. Agroforestryenhanced biodiversity: the good, the bad and the unknown. pp. 207-215. In: Rietveld W. (ed.), Agroforestry and Sustainable Systems: Symposium Proceedings; 1994, August-10: Fort Collins, CO. General Technical Report RM-GTR-261. Fort Collins, CO: US Department of Agriculture, Forest Service, Rocky Mountain Forest \& Range Experiment Station.
Schroder J.M. and Jaenicke H. 1994. A computerized database as decision support tool for the selection of agroforestry tree species. Agroforest Syst 26: 65-70.

Sinclair F.L. 1996. The emergence of associative tree ideotypes from ecophysiological research and farmers' knowledge. Agroforest Forum 7: 17-19.

Sinclair F.L. and Walker D.H. 1998. Acquiring qualitative knowledge about complex agroecosystems. Part 1: representation as natural language. Agr Syst 56: 341-363.

Skidmore A. (ed.) 2002. Environmental Modelling with GIS and Remote Sensing. Taylor \& Francis Inc. London, UK. 268 pp.

Sunderic D. and Woodhead T. 2001. SQL Server 2000: Stored Procedure Programming. McGraw-Hill Professional. Berkeley, CA. $732 \mathrm{pp}$.

Timlin D.J., Pachepsky Y.A., Whisler F.D. and Reddy V.R. 2002. Experience with onfarm applications of GLYCIM/GUICS. pp. 55-69. In: Ahuja L.R., Ma L. and Howell T.A. (eds), Agricultural System Models in Field Research and Technology Transfer. Lewis Publishers. Boca Raton, FL.

Turner B.J. and Church R. 1995. Review of the use of the FORPLAN (FORest PLANning) model. Department of Conservation and Natural Resources, Victoria, Australia. 25 pp.

Twery M.J., Rauscher M.H., Bennett D.J., Thomasma S.A., Stout S.L., Palmer J.F., Hoffman R.E., DeCalesta D.S., Gustafson E., Cleveland H., Grove J.M., Nute D., Kim G. and Kollasch P.R. 2000. NED-1: integrated analyses for forest stewardship decisions. Computers and Electronics in Agriculture 27: 167-193.

Twery M.J., Rauscher M., Knopp P.D., Thomas S.A., Nute D.E., Potter W.D., Maier F., Wang J., Dass M., Uchiyama H. and Glende A. 2003. NED-2: An integrated forest ecosystem management decision support system. pp. 1-11. In: Vacik H., Lexer M.J., Rauscher M.H., Reynolds K.M. and Brooks R.T. (eds), Decision Support for Multiple Purpose Forestry. A Transdisciplinary Conference on the Development and Application of Decision Support Tools for Forest Management. 23-25 April 2003, University of Natural Resources and Applied Life Sciences, Vienna Austria, CD-ROM.

Unruh J.D. and Lefebvre P.A. 1995. A spatial database approach for estimating areas suitable for agroforestry in sub-Saharan Africa: aggregation and use of agroforestry case studies. Agroforest Syst 32: 81-96.

van Noordwijk M. 2002 Scaling trade-offs between crop productivity, carbon stocks and biodiversity in shifting cultivation landscape mosaics: the FALLOW model. Ecol Model 149: $113-126$.

van Noordwijk M. and Lusiana B. 1999. WaNuLCAS, a model of nutrient and light capture in agroforestry systems. pp. 217-242. In: Auclair D. and Dupraz C. (eds), Agroforestry for Sustainable Land-Use Fundamental Research and Modelling with Emphasis on Temperate and Mediterranean Applications. Kluwer Academic Publishers. Dordrecht, The Netherlands.

van Noordwijk M. and Lusiana B. 2000. WaNuLCAS version 2.0, Background on a Model of Water Nutrient and Light Capture in Agroforestry Systems. International Centre for Research in Agroforestry (ICRAF). Bogor, Indonesia. $186 \mathrm{pp}$.

Vermeulen S.J., Woomer P., Campbell B.M., Kamukondiwa W., Swift M.J., Frost P.G.H., Chivaura C., Murwira H.K., Mutambanengwe F. and Nyathi P. 1993. Use of the SCUAF model to simulate natural miombo woodland and maize monoculture ecosystems in Zimbabwe. Agroforest Syst 22: 259-271.

von Carlowitz P.G., Wolf G.V. and Kemperman R.E.M. 1991. Multipurpose Tree and Shrub Database: An Information and Decision Support System. ICRAF, Nairobi, Kenya \& GTZ, Eschborn, Germany. 104 pp. 
World Agroforestry Centre 2003a. Agroforestry Database. http:// www.worldagroforestrycentre.org/Sites/TreeDBS/AFT/AFT.htm Accessed June 15, 2003.

World Agroforestry Centre 2003b. WaNuLCAS: A model of Water Nutrient and Light Capture in Agroforestry Systems. http:// www.worldagroforestrycentre.org/sea/agromodels/WaNuLCAS/ index.htm Accessed June 15, 2003.

World Agroforestry Centre 2003c. Forest, Agroforest, Lowvalue Landscape or Wasteland? http://www. worldagroforestrycentre.org/sea/agromodels/FALLOW/fallow.htm Accessed June 15,2003

World Agroforestry Centre 2003d. Training on Local Ecological knowledge (LEK) and Knowledge-based systems (KBS). Chiang Mai, Thailand: 8-12 June 2001. http://www. worldagroforestrycentre.org/sea/Products/training/

GroupTra/LEK/\#Objectives Accessed September 12, 2003.

Walker D.H. and Lowes D. 1997. Natural resource management: opportunities and challenges in the application of decision support systems. AI Applications 11(2): 41-51.

Walker D.H. and Sinclair F.L. 1998. Acquiring qualitative knowledge about complex agroecosystems. Part 2: formal representation. Agr Syst 56: 365-386.

Walker D.H., Sinclair F.L. and Kendon G. 1995. A knowledgebased system approach to agroforestry research and extension. AI Applications 9: 61-72.
Warkentin M.E., Nair P.K.R., Ruth S.R. and Sprague K. 1990. A knowledge-based expert system for planning and design of agroforestry systems. Agroforest Syst 11: 71-83.

Willis R.W. and Thomas T.H. 1997. POPMOD: A Bioeconomic Agroforestry Model. The BEAM Project. School of Agricultural and Forest Sciences, University of Wales, Bangor, UK. 13 pp.

Willis R.W., Thomas T.H., van Slycken J. 1993. Poplar agroforestry: a re-evaluation of its economic potential on arable land in the United Kingdom. Forest Ecol Manag 57: 85-97.

Wu J. and Hobbs R. 2002. Key issues and research priorities in landscape ecology: an idiosyncratic synthesis. Landscape Ecol 17: 355-365.

Young A. and Muraya P. 1990. SCUAF: Soil Changes Under Agroforestry. ICRAF, Nairobi. $124 \mathrm{pp}$.

Zazueta S.P. and Xin J. 1998. Computers in Agriculture: Proceedings of the 7th International Conference. Orlando, Florida, October 26-30. American Society of Agricultural Engineers, St. Joseph, MI. 999 pp.

Zeiler M. 1999. Modeling our World: the ESRI guide to geodatabase design. ESRI Press. Redlands, CA. 199 pp. 